\title{
Trace elements in scalp hair of leukaemia patients
}

\author{
Ali Khuder, \\ Mohammad Adel Bakir, \\ Reem Hasan, \\ Ali Mohammad, \\ Khozama Habil
}

\begin{abstract}
The aim of this study was to determine the concentration of $\mathrm{Fe}, \mathrm{Ni}, \mathrm{Cu}, \mathrm{Zn}$ and $\mathrm{Pb}$ in scalp hair of leukaemia patients and healthy volunteers, using the optimised XRF method. Leukaemia hair samples were classified corresponding to type, growth and age of the participants. The results showed that the studied trace elements (TEs) in both of leukaemia and control groups were positively skewed. In comparison with the control group, lower $\mathrm{Fe}, \mathrm{Cu}, \mathrm{Zn}$ and $\mathrm{Pb}$ and higher of $\mathrm{Ni}$ medians were found in all studied leukaemia patients. The median rank obtained by Mann-Whitney $U$-test revealed insignificant differences between the leukaemia patients subgroups and the controls. An exact probability $(\alpha<0.05)$ associated with the $U$-test showed significant differences between medians in leukaemia patients and controls groups for $\mathrm{Pb}$ (lymphatic/control, acute/control), $\mathrm{Cu}$ (lymphatic/control, chronic/control), Ni (lymphatic/control, chronic/control) and Fe (chronic/control). Very strong positive and negative correlations $(r>0.70)$ in the scalp hair of control group were observed between $\mathrm{Ni} / \mathrm{Fe}-\mathrm{Ni}, \mathrm{Cu} / \mathrm{Fe}-\mathrm{Cu}, \mathrm{Zn} / \mathrm{Fe}-\mathrm{Zn}$, Pb/Fe-Pb, Cu/Ni-Zn/Ni, Cu/Ni-Pb/Ni, Zn/Ni-Pb/Ni, Zn/Fe-Zn/Cu, Pb/Ni-Ni and $\mathrm{Ni} / \mathrm{Fe}-\mathrm{Pb} / \mathrm{Ni}$, whereas only very strong positive ratios in the scalp hair of leukaemia patients group were observed between $\mathrm{Ni} / \mathrm{Fe}-\mathrm{Ni}, \mathrm{Cu} / \mathrm{Fe}-\mathrm{Cu}, \mathrm{Zn} / \mathrm{Fe}-\mathrm{Zn}$ and $\mathrm{Pb} / \mathrm{Fe}-\mathrm{Pb}$, all correlations were significant at $p<0.05$. Other strong and significant correlations were also observed in scalp hair of both groups. Significant differences between grouping of studied TEs in all classified leukaemia groups and controls were found using principal component analysis (PCA). The results of PCA confirmed that the type and the growth of leukaemia factors were more important in element loading than the age factor.
\end{abstract}

Key words: leukaemia $\bullet$ principal component analysis $\bullet$ scalp hair $\bullet U$-test $\bullet$ X-ray fluorescence

\author{
A. Khuder ${ }^{\bowtie}$, R. Hasan \\ Department of Chemistry, \\ Atomic Energy Commission of Syria (AECS), \\ P. O. Box 6091, Damascus, Syria, \\ Tel.: +96311213 2580, Fax: +963116112289, \\ E-mail: cscientific@aec.org.sy \\ M. A. Bakir, A. Mohammad, K. Habil \\ Department of Radiation Medicine, \\ Atomic Energy Commission of Syria (AECS), \\ P. O. Box 6091, Damascus, Syria
}

Received: 3 July 2013

Accepted: 13 June 2014

\section{Introduction}

Nowadays, the investigation of trace elements (TEs) in the body fluids and tissues of living persons has been correlated to the diagnosis of various diseases, including cancers such prostate, leukaemia, colorectal, lung, liver, kidney, thyroid and breast [1-7]. Even though the biochemical mechanism of these elements for the cause of cancer in human body is not very clear in the present stage, from the perspective of cancer prevention and diagnosis. However, the studies on the relationship between the cause of cancer and the levels of elements are still of great importance.

Among the different biological specimens subjected for analysis, hair has attracted considerable attention because of the simplicity of sampling, transport and handling as well as providing information about concentrations of some TEs that are considerably more concentrated in hair than in other biological specimens, which makes analysis easier $[8,9]$. Unfortunately, in some cases, collection of 
hair samples is considered problematic because of the reason of human hair loss, e.g. the case of individuals suffering from some cancerous diseases, including leukaemia [10].

In order to determine TEs in samples with critical amounts, very sensitive techniques were required. In this respect, techniques such inductively coupled plasma-mass spectrometry (ICP-MS), graphite furnace atomic absorption spectrometry (GFAAS), combustion atomic absorption spectrometry (Comb-AAS), neutron activation analysis (NAA) and total reflection X-ray fluorescence (TRXRF) could play a great role to overcome the limitation in sample amounts and the very small concentrations of some TEs [11-16]. In addition to the previously mentioned techniques, energy dispersive X-ray fluorescence (EDXRF) with modern software and combination with chemical procedures also showed a very good capability to determine several TEs with small concentrations $[14,17,18]$.

In this work, several TEs, i.e. $\mathrm{Fe}, \mathrm{Ni}, \mathrm{Cu}, \mathrm{Zn}$ and $\mathrm{Pb}$ in small available amounts of scalp hair of leukaemia patients were determined using the optimised calibration curve method for XRF. The TEs levels in leukaemia and control groups were subjected for statistical estimation using Mann-Whitney $U$-test and a multivariate method of principal component analysis (PCA). Hair TEs levels were also compared with those contents found in control group samples. Moreover, the possible association of hair TEs contents was investigated.

\section{Experimental}

\section{Study population}

Thirty-nine of leukaemia male patients, ages between 16 and 93 years, were participated in this study on voluntary basis. The average age of the patients was 49.0 years. The participated patients were selected from individuals admitted in Al-Mowasat hospital in Damascus city, Syria. Prior to the hair scalp sample collection, the protocol of the study was approved by the Human Ethical Committee of the respective hospital. Diagnosis of leukaemia was confirmed histologically. In order to determine the normal concentrations of TEs, 39 hair samples from volunteers, ages between 6 and 63 years were collected; all volunteers were healthy and not receiving any medication. Average age of the healthy volunteers was 34.3 years. The hair samples were collected from the nape of the scalp by cutting 3-5 $\mathrm{mm}$ hair pieces long using a pair of sterilised stainless steel scissor washed with ethanol, a neutral solvent to remove external contamination. Then, the collected hair samples were sealed in transparent plastic bag. Adequate masses $(>0.10 \mathrm{~g}$ ) of hair samples from individuals in control group were collected; while hair samples with masses in the range 0.05-0.10 g were available for leukaemia patients. Each sample was given a code number to correspond to the respondent. Simultaneously, their age, working duration and clinical history were recorded.

\section{Sample preparation}

The hair samples were subjected to the surface cleaning treatment according to IAEA recommendation [5]. The hair samples (about $0.050 \mathrm{~g}$ each) were prepared for XRF analysis using the procedure reported by Khuder et al. [14]. This included, however, the digestion of hair samples by a mixture of $\mathrm{HNO}_{3}-\mathrm{H}_{2} \mathrm{O}_{2}$ (3:1), the precipitation of studied TEs using ammonium pyrrolidinedithiocarbamate (APDC), and the filtration of the obtained precipitates using $0.45-\mu \mathrm{m}$ pore size filter paper. Then, the filters obtained were put in polyethylene cups, having sample area of approximately $3.97 \mathrm{~cm}^{2}$. The cups were covered from one side with Mylar foils. Finally, the samples were kept in desiccators for further analysis by XRF.

\section{Reagents and solutions}

All aqueous solutions and dilutions were prepared with ultrapure water, which was obtained from a water purification system (New Human Power II, South Korea) with $18.3 \mathrm{M} \Omega \mathrm{cm}$ specific resistivity. Analytical grade acetone (Merck) and ultrapure water were used for washing the scalp hair samples. Solutions of $14 \mathrm{HNO}_{3}(\mathrm{BDH})$, and $30 \% \mathrm{H}_{2} \mathrm{O}_{2}$ (Fluka) were used for the digestion of scalp hair samples. APDC analytical grade (Merck) was used for the co-precipitation of TEs. Stock standard solutions $(1000 \mu \mathrm{g} / \mathrm{ml})$ of $\mathrm{Fe}, \mathrm{Ni}$, $\mathrm{Cu}, \mathrm{Zn}$ and $\mathrm{Pb}$ from $\mathrm{BDH}$ were used for constructing of the calibration curves. For adjusting the $\mathrm{pH}$ of TEs, $25 \%$ ammonia solution (GR, Merck) was used.

The XRF method was tested using standard reference materials of human hair 085 from International Atomic Energy Agency (IAEA), human hair BCR-397 and mussel tissue BCR 278 from Community Bureau of Reference-BCR.

\section{Instrumental measurements}

The XRF measurements were carried out using an energy dispersive X-ray fluorescence instrument. The XRF technique was equipped with $2 \mathrm{KW}$ Mo tube and a $\mathrm{Si}(\mathrm{Li})$ semiconductor detector (PGT Co.) with an energy resolution of $160 \mathrm{eV}$ at $5.9 \mathrm{keV}$. The operating conditions were $20 \mathrm{~mA}$ and $35 \mathrm{kV}$ using Mo secondary target for X-ray excitation. The live time was $4000 \mathrm{~s}$.

Net peak intensities of $\mathrm{K} \alpha$ of $\mathrm{Fe}, \mathrm{Ni}, \mathrm{Cu}$ and $\mathrm{Zn}$, and $\mathrm{L} \alpha$ of $\mathrm{Pb}$ lines of the standards and the unknown hair samples were calculated by fitting the obtained spectra with the AXIL (analysis of X-ray spectra by iterative least squares fitting) program [19]. To ensure a careful control on probable contamination produced during the sample preparation and/or the measurements, blank sample was prepared for each set of samples.

\section{Validity of XRF method}

To determine the functional dependency associating the XRF intensity with the element concentration, the linear regression method was used. This method 
was also used in the determination of some important validation parameters. Microsoft Excel-2010 was used to calculate the regression parameters of the linear calibration curves. The correlation coefficients $(r)$ of the calibration curves were considered as parameters, which could only demonstrate the strength of the linear relationship between the intensity and the concentration. In this work, further parameters were examined to prove the linearity of the calibration curves. These were as follows:

\section{Slop and intercept}

Student's $t$-test at significant level $(\alpha)$ of 0.05 was used to examine the significance of the differences in the slope and the intercept of the calibration lines and the zero.

\section{Limit of detection (LOD), limit of quantitation (LOQ) and range}

The LOD and the LOQ values were calculated by the method reported by Konieczka and Namiesnik [20]. However, LOD values were calculated using the following dependence: $\mathrm{LOD}=3.3 \times \mathrm{SD} / b$; where $\mathrm{SD}$ and $b$ are the standard deviation and the slope of the corresponding calibration curves, respectively. The SD values were calculated by averaging the values of the residual standard deviation $\left(\mathrm{SD}_{x y}\right)$ and the standard deviation of the intercepts $\left(\mathrm{SD}_{a}\right)$ of the calibration curves each; taking into account that the previously mentioned parameters were obtained by drawing the calibration curves at three concentration levels closed to the expected LOD for hair samples. The correctness of the calculated LOD was estimated by respecting the following conditions: $10 \mathrm{LOD}>\mathrm{C}_{\min }$ and LOD $<\mathrm{C}_{\min }$; where $\mathrm{C}_{\min }$ is the lowest concentration used to draw the calibration curve. Depending on the calculated LOD, LOQ values were simply calculated by multiplying LOD by 3 .

The standard solutions were prepared with a suitable range of concentrations to cover those concentrations of TEs in unknown hair samples. Practically, the measuring range was identified by the interval between the LOQ and the highest element concentration for which a measuring XRF system showed an increase in the correspondent intensity.

\section{Accuracy and precision}

The accuracy was estimated by the relative difference between the obtained and the certified values. The precision of XRF measurements was estimated by the relative standard deviation, $\mathrm{RSD}=\left(\mathrm{SD} / \mathrm{C}_{\mathrm{ob}}\right) \times$ 100 , where $C_{o b}$ is the obtained concentration of the determined TEs. RSD was checked by repeating the measurements of each standard sample five times under the same operating conditions and during one working-day.

\section{Intermediate precision (ruggedness)}

To test the intermediate precision (IP), five independent aliquots of the used standard samples were prepared by the optimised XRF method. Then, each sample was measured as previously mentioned for the precision testing. The last process was carried out over five working-days. Finally, ANOVA single factor was applied to test the significant differences between the data analysis.

\section{Statistical analysis}

Student's $t$-test $(p<0.05)$ was used to study the quality of regression parameters obtained for calibration curves. ANOVA single factor was used to determine the stability of XRF method over a relatively long-term process of measuring. Mann-Whitney $U$-test was used to show the significant differences between the medians of the TEs in both leukaemia patients and control groups. Pearson correlation analysis was used to investigate the mutual relations between each pair of TEs. In addition, a multivariate technique of PCA [21] was used to find the possible sources and grouping of studied elements in the scalp hair of leukaemia patients and compare these results with those obtained for the control group. All calculations were performed using statistical packages STATISTICA-8 [22].

\section{Results and discussion}

\section{Validity of XRF method}

The important parameters required for validation of the XRF method were described in the previous section. However, the regression parameters, such the slopes $(S)$, the intercepts $(a)$ and the regression coefficients $(r)$ of the calibration curves were determined and displayed in Table 1 . The results revealed gradual increases in sensitivities $(S)$ of TEs of $\mathrm{K} \alpha$-lines, i.e. $\mathrm{Fe}, \mathrm{Ni}, \mathrm{Cu}$ and $\mathrm{Zn}$. Slightly decrease in $S$ of Pb-L $\alpha$

Table 1. The linear calibration curve equations of TEs

\begin{tabular}{lccrc}
\hline Element & $\begin{array}{c}\text { Regression coefficient, } \\
r\end{array}$ & $\begin{array}{c}\text { Slope, } b \\
\text { Cps/ } \mu \mathrm{g}\end{array}$ & $\begin{array}{c}\text { Intercept, } a \\
\text { (cps) }\end{array}$ & $\begin{array}{c}\text { Linear equation }^{\mathrm{a}}, \\
y=b x+a\end{array}$ \\
\hline $\mathrm{Fe}$ & 0.9989 & 0.247 & -0.004 & $y=0.247 x-0.004$ \\
$\mathrm{Ni}$ & 0.9951 & 0.291 & 0.004 & $y=0.291 x+0.004$ \\
$\mathrm{Cu}$ & 0.9987 & 0.321 & 0.007 & $y=0.321 x+0.007$ \\
$\mathrm{Zn}$ & 0.9985 & 0.485 & -0.094 & $y=0.485 x-0.094$ \\
$\mathrm{~Pb}$ & 0.9979 & 0.301 & -0.013 & $y=0.301 x-0.013$ \\
\hline
\end{tabular}

${ }^{a}$ The linear equation was obtained by drawing the measured intensities (cps) vs. the absolute concentrations of TEs in used standards. 


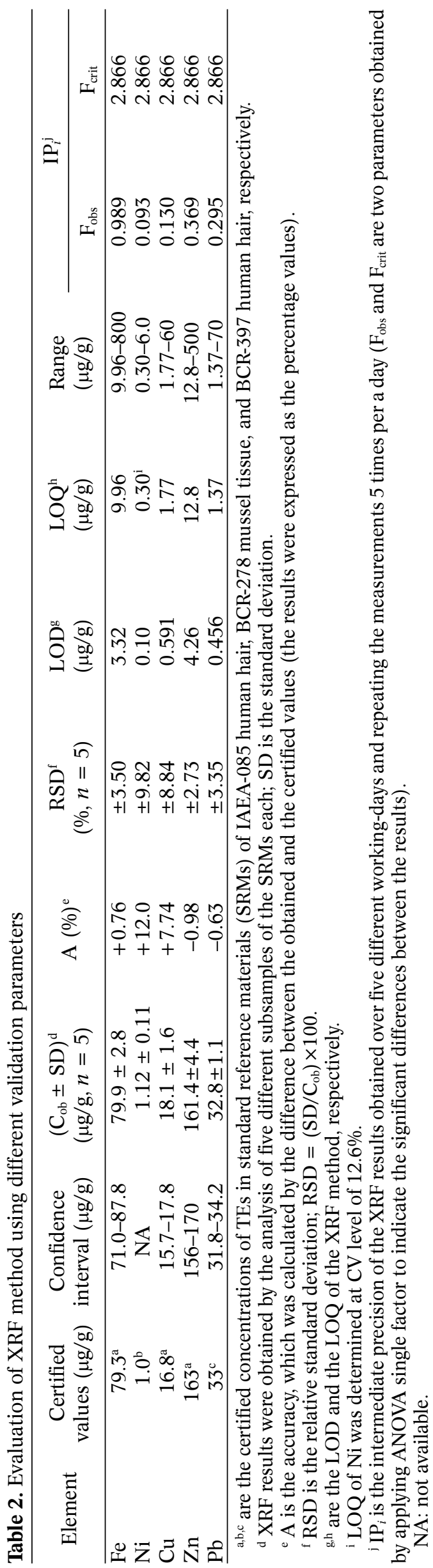

line was obtained in comparison to those obtained for $\mathrm{Cu}$ - and $\mathrm{Zn}-\mathrm{K} \alpha$ lines. Student's $t$-test at 0.05 significance level confirmed the significant differences between the slops of the calibration curves each and zero, in addition to the absence of the significant differences between the intercept values and zero. The $r$ values of the plotted calibration curves were better than 0.995, demonstrating good strengths of the linear relationship between the intensity and the concentration of the calibrated elements.

Other important parameters, characterising the XRF method, i.e. LOD, LOQ, range, accuracy, precision and intermediate precision, were also determined. The results of these parameters are displayed in Table 2. The correctness of LOD and hence LOQ values were tested according to the conditions mentioned in previous section. The LOD values of the five TEs studied varied between $0.10 \mu \mathrm{g} / \mathrm{g}$ for Ni and $4.26 \mu \mathrm{g} / \mathrm{g}$ for $\mathrm{Zn}$. These values confirmed the suitability of the XRF method for the determination of expected concentrations of studied TEs in hair samples. In fact, determining LOD and LOQ allowed the unequivocal determination and presentation of the results in the proximity of these values. The results also showed the suitable working range used for calibration of the studied TEs.

The accuracy of the XRF method was estimated by the analysis of five different subsamples $(n=5)$ of the IAEA-085, BCR-397 and BCR 278 standard reference samples each. The results showed the good agreement between the obtained concentrations and the certified values with errors less than $7.8 \%$ for all studied TEs, except $\mathrm{Ni}$, which was determined with error of $12.0 \%$, depending on the ratio of the $\mathrm{Ni}$ concentration in the used standard to the LOQ value. The precision of the XRF method was evaluated in terms of the relative standard deviation (RSD\%). The results showed that the RSD $\%$ was strictly dependent on the concentration levels of the determined TEs. Thus, $\mathrm{Ni}$ and $\mathrm{Cu}$ were determined with RSD value of $\pm 9.82 \%$ and $\pm 8.84 \%$ at the concentration level of 1.0 and $16.8 \mu \mathrm{g} / \mathrm{g}$, respectively; while the rest of the TEs were determined with RSD values better than $\pm 3.5 \%$.

Finally, the significant differences between the data analyses obtained over five working-days (data of the intermediate precision, last column in Table 2) were tested using ANOVA single factor. The results showed that, the values of F-test $\left(\mathrm{F}_{\mathrm{obs}}\right)$ were less than that for $\mathrm{F}_{\text {crit }}$, confirming that, there were no significant differences between the concentration values and the tested method was rugged.

\section{Distribution of elements}

Prior to other statistics, distribution of TEs in scalp hair was examined. The results showed that all TEs in leukaemia patients and control groups were positively skewed. Table 3 presents data of the mean, the median, the range and the coefficient of variance $(\mathrm{CV} \%)$ of the TEs levels in scalp hair of leukaemia patients (L) and control (C) groups, in addition to the concentrations of the reference values. The mean concentrations of $\mathrm{Fe}, \mathrm{Ni}$ and $\mathrm{Cu}$ were calculated 
Table 3. Concentrations of TEs in scalp hair of leukaemia patients (L) and control groups (C)

\begin{tabular}{lccccccc}
\hline Element & Group & $\begin{array}{c}\text { Valid } \\
\text { number }\end{array}$ & $\begin{array}{c}\text { Mean } \\
(\mu \mathrm{g} / \mathrm{g})\end{array}$ & $\begin{array}{c}\text { Median } \\
(\mu \mathrm{g} / \mathrm{g})\end{array}$ & $\begin{array}{c}\text { Range } \\
(\mu \mathrm{g} / \mathrm{g})\end{array}$ & $\begin{array}{c}\mathrm{CV} \% \\
(\mu \mathrm{g} / \mathrm{g})\end{array}$ & $\begin{array}{c}\text { Reference values } \\
\mathrm{Pb}\end{array}$ \\
\hline $\mathrm{C}$ & 37 & 10.9 & 9.88 & $5.81-22.1$ & 33.3 & $6.5-8.7[26]$ \\
$\mathrm{Zn}$ & $\mathrm{L}$ & 35 & 8.28 & 8.14 & $2.37-22.3$ & 60.6 & $3-17[7], 3.3-99.1[4]$ \\
& $\mathrm{C}$ & 36 & 218 & 200 & $84.0-488$ & 43.5 & $171-314[27]$ \\
$\mathrm{Cu}$ & $\mathrm{L}$ & 38 & 183 & 164 & $36.0-466$ & 53.1 & $89-170[24], 110-1092[23]$ \\
& $\mathrm{C}$ & 39 & 15.5 & 13.1 & $5.97-43.2$ & 49.8 & $10-21[27]$ \\
$\mathrm{Ni}$ & $\mathrm{L}$ & 39 & 12.1 & 8.90 & $1.80-32.6$ & 66.6 & $7-22[24], 9-83[23]$ \\
& $\mathrm{C}$ & 39 & 1.30 & 0.94 & $0.296-3.19$ & 66.7 & $1.4-3.2[27]$ \\
$\mathrm{Fe}$ & $\mathrm{L}$ & 39 & 2.32 & 1.94 & $0.290-7.34$ & 76.7 & $1.1-4.3[24], 0.7-1.61[26]$ \\
& $\mathrm{C}$ & 39 & 35.2 & 33.5 & $24.5-74.0$ & 23.1 & $22-61[15]$ \\
& $\mathrm{L}$ & 39 & 38.4 & 31.4 & $17.9-149$ & 69.9 & $25-50[26], 90-204[9]$ \\
\hline
\end{tabular}

by considering all analysed hair samples, while the mean concentrations of $\mathrm{Pb}$ in leukaemia and control groups were calculated for 72 samples of 78 participated individuals, having $\mathrm{Pb}$ concentrations above the detection limits of the XRF method. The mean concentrations of $\mathrm{Zn}$ in leukaemia and control groups were determined for 74 samples of 78 individuals; taking into account that 4 samples with $\mathrm{Zn}$ concentrations greater than the maximum concentration of the calibration curve were not considered in determination of $\mathrm{Zn}$ mean. Overall, the concentration ranges of the TEs in scalp hair of healthy individuals were in the same order of those reported elsewhere $[9,23-25,27]$. The results showed a relatively wide concentration range of the studied TEs in the control group with $\mathrm{CV} \%$ values in the range from $23.1 \%$ for Fe to $66.7 \%$ for Ni. These indications were at most due to the large variations in the individual results in the control group. In the instance of leukaemia group, the CV\% values (from $53.1 \%$ for $\mathrm{Zn}$ to $76.7 \%$ for $\mathrm{Ni}$ ) were higher than those obtained for the control group. This concluded, however, the presence of additional factors affected the distribution of the TEs in scalp hair of leukaemia patients.

The highest mean concentration of the determined TEs in control group was observed for $\mathrm{Zn}$ $(218 \mu \mathrm{g} / \mathrm{g})$, followed by Fe $(35.2 \mu \mathrm{g} / \mathrm{g}), \mathrm{Cu}(15.5 \mu \mathrm{g} / \mathrm{g})$, $\mathrm{Pb}(10.9 \mu \mathrm{g} / \mathrm{g})$ and $\mathrm{Ni}(1.30 \mu \mathrm{g} / \mathrm{g})$. The previously mentioned decreasing order was also mentioned for the same TEs in leukaemia patients group with the following means: $183 \mu \mathrm{g} \mathrm{Zn/g,} 38.4 \mu \mathrm{g} \mathrm{Fe} / \mathrm{g}, 12.1 \mu \mathrm{g}$ $\mathrm{Cu} / \mathrm{g}, 8.28 \mu \mathrm{g} \mathrm{Pb} / \mathrm{g}$ and $\mathrm{Ni} 2.32 \mu \mathrm{g} \mathrm{Ni} / \mathrm{g}$.

For further studies of TEs distributions, leukaemia patients group was divided into two subgroups according to the type of the affected cells: (i) lymphocytic leukaemia (LL, $n=16$ ), which affected lymphoid cells; and (ii) myeloid leukaemia (ML, $n=23$ ), which affected myeloid cells. The leukaemia patients group was also divided into two other subgroups according to the growth of leukaemia. However, these were: (iii) chronic leukaemia (CL, $n=26$ ); and (iv) acute leukaemia (AL, $n=13$ ). Accordingly, the ratios of medians in different leukaemia patients subgroups to those in controls were calculated and plotted against the examined TEs (Fig. 1). Although the tendencies toward the lower medians of $\mathrm{Fe}, \mathrm{Cu}$, $\mathrm{Zn}$ and $\mathrm{Pb}$ and the higher median of Ni were shown,

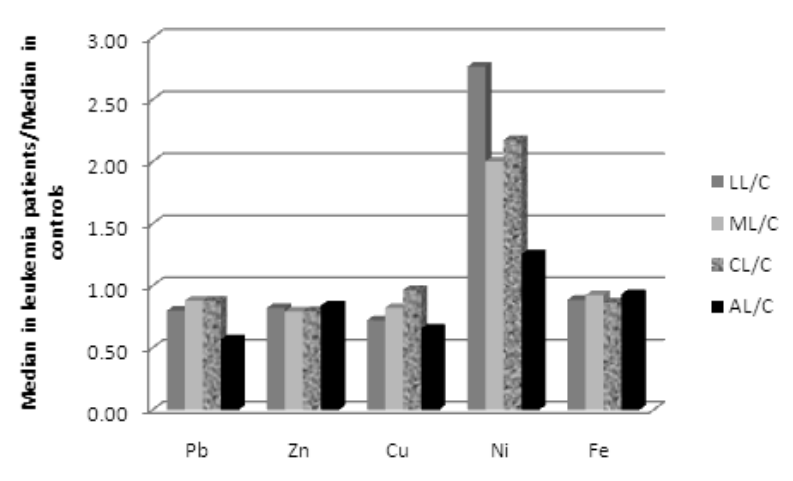

Fig. 1. Ratios of medians of TEs in leukaemia patients subgroups and controls. Where LL, ML, CL, AL and $\mathrm{C}$ are the lymphocytic leukaemia, myeloid leukaemia, chronic leukaemia, acute leukaemia and control groups, respectively.

the median ranks obtained by using Mann-Whitney $U$-test, $p>0.05$ (Fig. 2 ) revealed insignificant differences between the TEs in both of leukaemia patients subgroups and control group. An exact probability $(\alpha<0.05)$ associated with the respective $U$ statistic was also computed to show the significant differences between the medians of the examined TEs in different leukaemia patients patterns and control group. The results in Table 4 showed significant differences of medians of $(\mathrm{Pb}, \mathrm{Ni}$ and $\mathrm{Cu}),(\mathrm{Ni}$ and $\mathrm{Fe})$ and $(\mathrm{Pb}$ and $\mathrm{Cu}$ ) in LL, CL and AL subgroups, respectively, in comparison to those obtained for control group; while the results of medians determined for all TEs in ML subgroup showed no significant differences compared to those obtained in control group.

\section{Correlation study}

The data on element-to-element, element-to-ratio and ratio-to-ratio correlations in the scalp hair samples of control and leukaemia patients subgroups are given in Table 5 and Table 6 , respectively. The results showed very strong positive correlations in the control group: $\mathrm{Ni} / \mathrm{Fe}-\mathrm{Ni}(r=0.97), \mathrm{Cu} / \mathrm{Fe}-\mathrm{Cu}$ $(r=0.96), \mathrm{Zn} / \mathrm{Fe}-\mathrm{Zn}(r=0.96), \mathrm{Pb} / \mathrm{Fe}-\mathrm{Pb}(r=$ $0.88), \mathrm{Cu} / \mathrm{Ni}-\mathrm{Zn} / \mathrm{Ni}(r=0.81), \mathrm{Cu} / \mathrm{Ni}-\mathrm{Pb} / \mathrm{Ni}(r=$ $0.75), \mathrm{Zn} / \mathrm{Ni}-\mathrm{Pb} / \mathrm{Ni}(r=0.75)$ and $\mathrm{Zn} / \mathrm{Fe}-\mathrm{Zn} / \mathrm{Cu}$ $(r=0.70)$. Two very strong negative correlations 

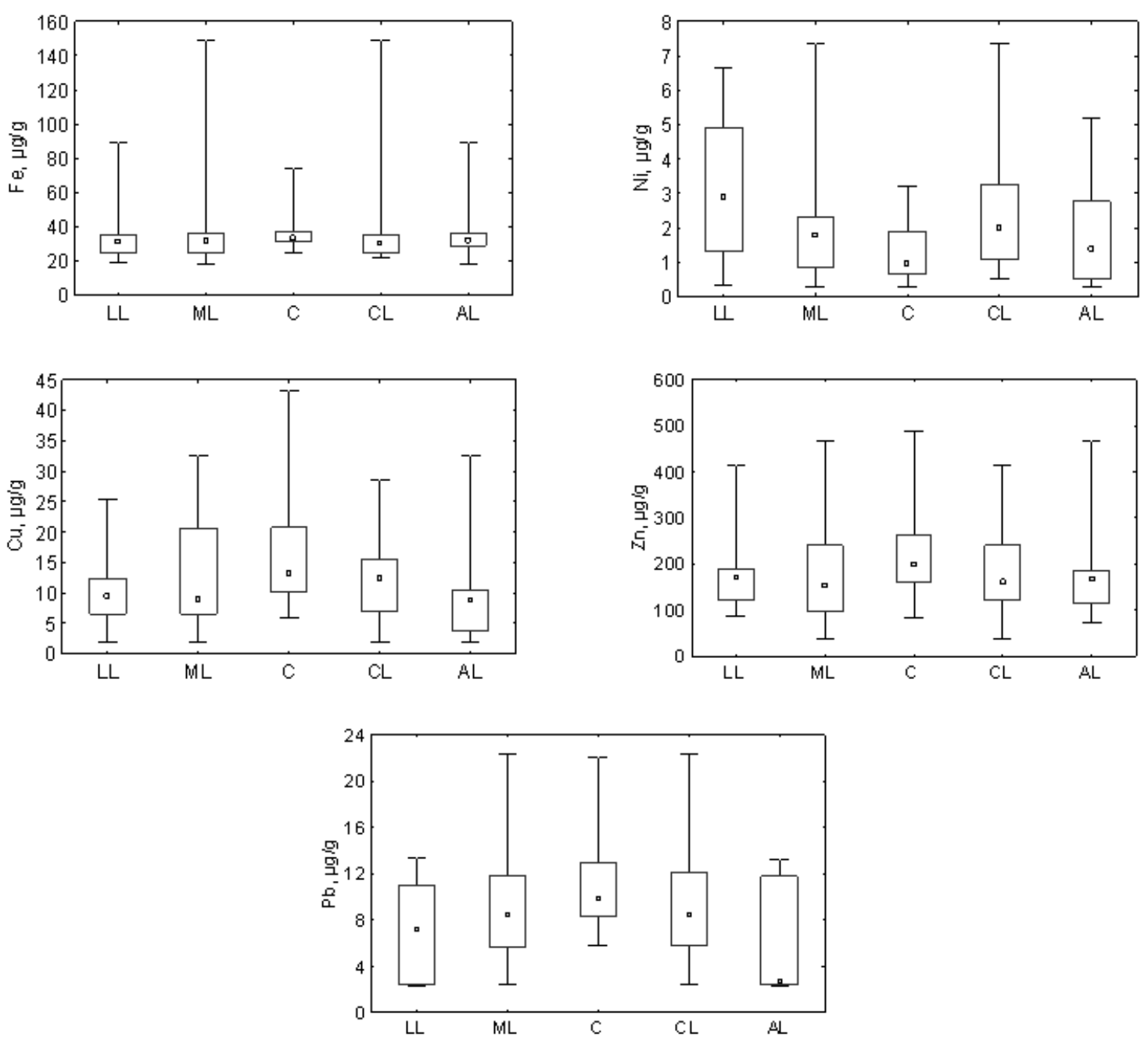

Fig. 2. Mann-Whitney $U$-test of scalp hair $\mathrm{Fe}, \mathrm{Ni}, \mathrm{Cu}, \mathrm{Zn}$ and $\mathrm{Pb}$ levels in leukaemia patients subgroups (LL, ML, $\mathrm{Cl}$ and AL) and controls (C). Differences were not significant. $\square$ Median, $\square$ 25\%-75\%, I Min-Max. The symbols are explained in Fig. 1.

Table 4. Significant differences between medians $(\mu \mathrm{g} / \mathrm{g})$ of the TEs in scalp hair of different leukaemia patient patterns and control group ${ }^{\mathrm{a}}$

\begin{tabular}{lcccc}
\hline \multirow{2}{*}{ Element } & \multicolumn{4}{c}{$p$-Level } \\
\cline { 2 - 5 } & LL/C & ML/C & CL/C & AL/C \\
\hline $\mathrm{Pb}$ & $\mathbf{0 . 0 1 8 8 7}(13,37)$ & $0.08046(22,37)$ & $0.07032(24,37)$ & $\mathbf{0 . 0 1 9 5 5}(11,37)$ \\
$\mathrm{Zn}$ & $0.19866(15,36)$ & $0.05290(23,36)$ & $0.08305(26,36)$ & $0.11988(12,36)$ \\
$\mathrm{Cu}$ & $\mathbf{0 . 0 0 8 4 7}(16,39)$ & $0.13803(23,39)$ & $0.15484(26,39)$ & $\mathbf{0 . 0 0 3 4 6}(13,39)$ \\
$\mathrm{Ni}$ & $\mathbf{0 . 0 0 1 2 4}(16,39)$ & $0.17207(23,39)$ & $\mathbf{0 . 0 0 1 8 6}(26,39)$ & $0.45148(13,39)$ \\
$\mathrm{Fe}$ & $0.07663(16,39)$ & $0.11606(23,39)$ & $\mathbf{0 . 0 3 6 6 8}(26,39)$ & $0.32478(13,39)$ \\
\hline
\end{tabular}

a Symbols of leukaemia patient patterns and controls are explained in Fig. 1.

Data between parentheses are the valid numbers of leukaemia subgroups and control group, respectively.

Marked tests are significant at $p<0.05$.

were also obtained: $\mathrm{Pb} / \mathrm{Ni}-\mathrm{Ni}(r=-0.80)$ and $\mathrm{Ni} / \mathrm{Fe}-$ $-\mathrm{Pb} / \mathrm{Ni}(r=-0.80)$. Other strong positive correlations were observed for $\mathrm{Ni}-\mathrm{Pb}, \mathrm{Pb} / \mathrm{Zn}-\mathrm{Zn}, \mathrm{Pb} /$ $\mathrm{Cu}-\mathrm{Pb}, \mathrm{Pb} / \mathrm{Fe}-\mathrm{Ni}, \mathrm{Zn} / \mathrm{Cu}-\mathrm{Zn}, \mathrm{Zn} / \mathrm{Cu}-\mathrm{Pb} / \mathrm{Cu}, \mathrm{Zn} /$ $\mathrm{Ni}-\mathrm{Ni}$ and $\mathrm{Ni} / \mathrm{Fe}-\mathrm{Pb} / \mathrm{Fe}$. Strong negative correlations were also obtained: $\mathrm{Pb} / \mathrm{Cu}-\mathrm{Cu}, \mathrm{Zn} / \mathrm{Cu}-\mathrm{Cu}$, $\mathrm{Zn} / \mathrm{Ni}-\mathrm{Pb} / \mathrm{Zn}, \mathrm{Zn} / \mathrm{Fe}-\mathrm{Pb} / \mathrm{Zn}, \mathrm{Cu} / \mathrm{Ni}-\mathrm{Ni}, \mathrm{Cu} /$ $\mathrm{Ni}-\mathrm{Pb} / \mathrm{Cu}, \mathrm{Cu} / \mathrm{Fe}-\mathrm{Pb} / \mathrm{Cu}, \mathrm{Ni} / \mathrm{Fe}-\mathrm{Zn} / \mathrm{Ni}$ and $\mathrm{Ni} /$ $\mathrm{Fe}-\mathrm{Cu} / \mathrm{Ni}$. In addition, some significant positive and negative correlations were also obtained for: $\mathrm{Pb} / \mathrm{Zn}-\mathrm{Ni}, \mathrm{Pb} / \mathrm{Cu}-\mathrm{Pb} / \mathrm{Zn}, \mathrm{Pb} / \mathrm{Fe}-\mathrm{Zn}, \mathrm{Pb} / \mathrm{Fe}-\mathrm{Pb} /$ $\mathrm{Ni}, \mathrm{Pb} / \mathrm{Fe}-\mathrm{Pb} / \mathrm{Cu}, \mathrm{Zn} / \mathrm{Cu}-\mathrm{Pb} / \mathrm{Zn}, \mathrm{Zn} / \mathrm{Ni}-\mathrm{Pb}$,
$\mathrm{Zn} / \mathrm{Ni}-\mathrm{Zn}, \mathrm{Zn} / \mathrm{Ni}-\mathrm{Pb} / \mathrm{Cu}, \mathrm{Zn} / \mathrm{Ni}-\mathrm{Pb} / \mathrm{Fe}, \mathrm{Zn} / \mathrm{Fe}-\mathrm{Fe}$, $\mathrm{Zn} / \mathrm{Fe}-\mathrm{Pb} / \mathrm{Fe}, \mathrm{Zn} / \mathrm{Fe}-\mathrm{Zn} / \mathrm{Ni}, \mathrm{Cu} / \mathrm{Ni}-\mathrm{Pb}, \mathrm{Cu} / \mathrm{Ni}-\mathrm{Pb} /$ $\mathrm{Zn}, \mathrm{Cu} / \mathrm{Ni}-\mathrm{Pb} / \mathrm{Fe}, \mathrm{Cu} / \mathrm{Fe}-\mathrm{Zn} / \mathrm{Cu}, \mathrm{Cu} / \mathrm{Fe}-\mathrm{Zn} / \mathrm{Fe}, \mathrm{Cu} /$ $\mathrm{Fe}-\mathrm{Cu} / \mathrm{Ni}, \mathrm{Ni} / \mathrm{Fe}-\mathrm{Pb}$ and $\mathrm{Ni} / \mathrm{Fe}-\mathrm{Cu} / \mathrm{Fe}$. These results revealed that the relationship between pairs of TEs (element-to-element) in scalp hair of control group was observed only for $\mathrm{Ni}$ and $\mathrm{Pb}$; while numbers of the relationships were observed by correlating the ratios of the studied TEs by each other (element-to-ratio and ratio-to-ratio).

Very strong positive correlations were found in the leukaemia group: $\mathrm{Ni} / \mathrm{Fe}-\mathrm{Ni}(r=0.88), \mathrm{Cu} / \mathrm{Fe}-$ 

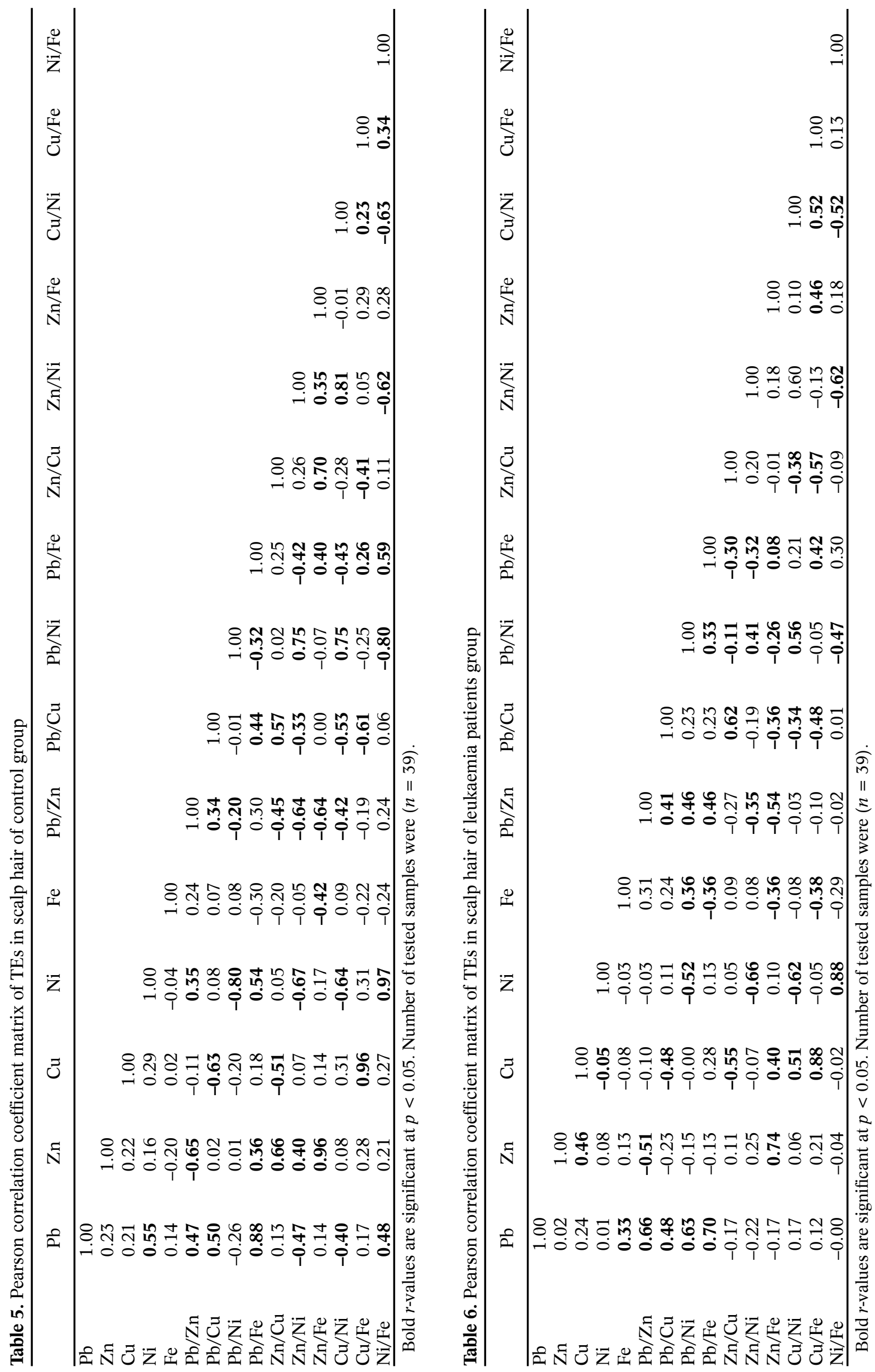
$-\mathrm{Cu}(r=0.88), \mathrm{Zn} / \mathrm{Fe}-\mathrm{Zn}(r=0.74), \mathrm{Pb} / \mathrm{Fe}-\mathrm{Pb}$ $(r=0.70)$. In addition, strong positive correlations $(\mathrm{Pb} / \mathrm{Zn}-\mathrm{Pb}, \mathrm{Pb} / \mathrm{Ni}-\mathrm{Pb}, \mathrm{Zn} / \mathrm{Cu}-\mathrm{Pb} / \mathrm{Cu}, \mathrm{Cu} / \mathrm{Ni}-\mathrm{Cu}$, $\mathrm{Cu} / \mathrm{Ni}-\mathrm{Pb} / \mathrm{Ni}$ and $\mathrm{Cu} / \mathrm{Fe}-\mathrm{Cu} / \mathrm{Ni}$ ) and strong negative correlations $(\mathrm{Pb} / \mathrm{Zn}-\mathrm{Zn}, \mathrm{Pb} / \mathrm{Ni}-\mathrm{Ni}, \mathrm{Zn} / \mathrm{Cu}-\mathrm{Cu}$, $\mathrm{Zn} / \mathrm{Ni}-\mathrm{Ni}, \mathrm{Zn} / \mathrm{Fe}-\mathrm{Pb} / \mathrm{Zn}, \mathrm{Cu} / \mathrm{Ni}-\mathrm{Ni}, \mathrm{Cu} / \mathrm{Fe}-\mathrm{Zn} /$ $\mathrm{Cu}, \mathrm{Ni} / \mathrm{Fe}-\mathrm{Zn} / \mathrm{Ni}, \mathrm{Ni} / \mathrm{Fe}-\mathrm{Cu} / \mathrm{Ni}$ ) were obtained. Numbers of other significant positive and negative correlations were also found: $\mathrm{Cu}-\mathrm{Zn}, \mathrm{Fe}-\mathrm{Pb}, \mathrm{Pb}$ / $\mathrm{Cu}-\mathrm{Pb}, \mathrm{Pb} / \mathrm{Cu}-\mathrm{Cu}, \mathrm{Pb} / \mathrm{Cu}-\mathrm{Pb} / \mathrm{Zn}, \mathrm{Pb} / \mathrm{Ni}-\mathrm{Fe}, \mathrm{Pb} / \mathrm{Ni}-$ - $\mathrm{Pb} / \mathrm{Zn}, \mathrm{Pb} / \mathrm{Fe}-\mathrm{Fe}, \mathrm{Pb} / \mathrm{Fe}-\mathrm{Pb} / \mathrm{Zn}, \mathrm{Pb} / \mathrm{Fe}-\mathrm{Pb} / \mathrm{Ni}, \mathrm{Zn} /$ $\mathrm{Cu}-\mathrm{Pb} / \mathrm{Ni}, \mathrm{Zn} / \mathrm{Cu}-\mathrm{Pb} / \mathrm{Fe}, \mathrm{Zn} / \mathrm{Ni}-\mathrm{Pb} / \mathrm{Zn}, \mathrm{Zn} / \mathrm{Ni}-\mathrm{Pb} /$ $\mathrm{Ni}, \mathrm{Zn} / \mathrm{Ni}-\mathrm{Pb} / \mathrm{Fe}, \mathrm{Zn} / \mathrm{Fe}-\mathrm{Cu}, \mathrm{Zn} / \mathrm{Fe}-\mathrm{Fe}, \mathrm{Zn} / \mathrm{Fe}-\mathrm{Pb} /$ $\mathrm{Ni}, \mathrm{Cu} / \mathrm{Ni}-\mathrm{Pb} / \mathrm{Cu}, \mathrm{Cu} / \mathrm{Ni}-\mathrm{Zn} / \mathrm{Cu}, \mathrm{Cu} / \mathrm{Fe}-\mathrm{Fe}, \mathrm{Cu} / \mathrm{Fe}-$ $-\mathrm{Pb} / \mathrm{Cu}, \mathrm{Cu} / \mathrm{Fe}-\mathrm{Pb} / \mathrm{Fe}$ and $\mathrm{Cu} / \mathrm{Fe}-\mathrm{Zn} / \mathrm{Fe}$. The results revealed some common origins of the studied TEs in the scalp hair of leukaemia patients. On the other hand, several important correlations for the TEs and their ratios in control group, e.g. Ni-Pb, $\mathrm{Zn}-\mathrm{Zn} / \mathrm{Cu}$ and $\mathrm{Ni}-\mathrm{Pb} / \mathrm{Fe}$, were not found in leukaemia patients group. Furthermore, the very strong correlation coefficients of the TEs and their ratios were much higher in control group than those obtained in leukaemia patients group, indicating the influence of higher variations obtained for concentrations of TEs in leukaemia patients in comparison to those obtained in control group on the inter-relationship between pairs of the studied TEs and their ratios. The previously mentioned results could suggest correlations between TEs and their ratios as a prognostic factor of leukaemia decease. Studies on correlations between TEs were reported elsewhere to determine the severity of diseases, including leukaemia [28, 29].

\section{Principal component analysis}

Three important factors: age, type and growth of leukaemia patients, which were expected to affect the source identification and grouping of TEs, were studied. Regarding the age factor, PCA was employed to identify the possible sources and grouping of studied TEs in scalp hair of control and the leukaemia age groups. The variables subjected to PCA were the concentrations of the TEs in scalp hair samples of control group and leukaemia patients. For this study, the individuals of control group were divided into two age-subgroups. The first age-subgroup $\left(\mathrm{G}_{\mathrm{c} 1}\right)$ was consisted of 33 older individuals with a range of age from 23 to 63 years (mean age 37.6 year), while the second age-subgroup $\left(\mathrm{G}_{\mathrm{c} 2}\right)$ was consisted of only six available younger individuals with a range of age from 6 to 22 years (mean age 16.0 year). The principal component (PC) loadings, which were extracted by using varimax normalised rotation on the TEs data-set, are shown in Table 7 . The results showed that three PCs loading were extracted with eigenvalues $>1$ for $G_{c 1}$ age-subgroup, while only two PCs loading were extracted with eigenvalues $>1$ for $\mathrm{G}_{\mathrm{c} 2}$; commutatively explaining more than 81 and $84 \%$ of the total variances, respectively. PC1 showed maximum loading for $\mathrm{Pb}$ and $\mathrm{Ni}$ in both of age-subgroups. In addition, PC2 showed maximum loading for Fe and $\mathrm{Zn}$ in the previously mentioned age-subgroups. One significant difference was mentioned between $\mathrm{G}_{\mathrm{c} 1}$ and $\mathrm{G}_{\mathrm{c} 2}$, corresponding to PC3, which showed maximum loading for $\mathrm{Cu}$ in $\mathrm{G}_{\mathrm{c} 1}$; while such maximum loading was absent in $\mathrm{G}_{\mathrm{c} 2}$ age-subgroup. As the result of existing the previously mentioned difference between the studied age subgroups and because the means of the ages of the studied leukaemia patients subgroups were extremely averaged toward the mean age of controls in $\mathrm{G}_{\mathrm{c} 1}$ subgroup, the results of PCA of last mentioned subgroup were considered in further studies for comparison. Similar study was also carried out on the data analysis corresponding to leukaemia patients group. The results revealed that there were no significant differences between PC loadings for all tested TEs in age-subgroups of leukaemia patients, confirming that the age factor was negligible in comparison to other expected factors such the type and the growth of leukaemia.

Regarding the type factor, PCA was also employed for LL and ML leukaemia subgroups and the results were compared to those obtained for the control group $\left(\mathrm{G}_{\mathrm{c} 1}\right)$. In a similar manner, PCA was employed for CL and AL leukaemia subgroups which reflected the effect of growth factor of leukaemia. The results of PCA loadings are shown in Tables 8 and 9 for (LL and ML) and (CL and AL) leukaemia subgroups, respectively. The results showed that, only two PCs were extracted with eigenvalues $>1$ for LL, ML, CL and AL leukaemia subgroups each, commutatively explaining more than $68,61,60$ and $77.8 \%$ of the total variance, respectively. In the instance of the control group, PC1 showed higher

Table 7. Principal component loadings of TEs in scalp hair of control age groups: $\left(\mathrm{G}_{\mathrm{c} 1}, n=33\right)^{\mathrm{a}}$ and $\left(\mathrm{G}_{\mathrm{c} 2}, n=6\right)^{\mathrm{b}}$ groups

\begin{tabular}{|c|c|c|c|c|c|c|}
\hline \multirow{2}{*}{ Variable } & \multicolumn{2}{|c|}{ PC1 } & \multicolumn{2}{|c|}{ PC2 } & \multicolumn{2}{|c|}{ PC3 } \\
\hline & $\mathrm{G}_{\mathrm{c} 1}$ & $\mathrm{G}_{\mathrm{c} 2}$ & $\mathrm{G}_{\mathrm{c} 1}$ & $\mathrm{G}_{\mathrm{c} 2}$ & $\mathrm{G}_{\mathrm{c} 1}$ & $\mathrm{G}_{\mathrm{c} 2}$ \\
\hline$\overline{\mathrm{Pb}}$ & 0.92 & 0.79 & -0.00 & 0.13 & 0.14 & - \\
\hline $\mathrm{Zn}$ & 0.22 & 0.41 & 0.74 & 0.90 & 0.32 & - \\
\hline $\mathrm{Cu}$ & -0.01 & 0.62 & 0.02 & 0.56 & 0.95 & - \\
\hline $\mathrm{Ni}$ & 0.91 & 0.97 & 0.01 & -0.13 & -0.10 & - \\
\hline $\mathrm{Fe}$ & 0.17 & -0.39 & -0.84 & 0.87 & 0.19 & - \\
\hline Eigenvalues & 1.76 & 2.49 & 1.28 & 1.72 & 1.02 & - \\
\hline Total variance $(\%)$ & 35.3 & 49.8 & 25.9 & 34.3 & 20.3 & - \\
\hline Cumulative variance (\%) & 35.3 & 49.8 & 61.2 & 84.1 & 81.5 & - \\
\hline
\end{tabular}

${ }^{\text {a }}$ PCA results of 33 hair samples collected from individuals aged from 23 to 63 years.

${ }^{\mathrm{b}}$ PCA results of six hair samples collected from individuals aged from 6 to 22 years.

Higher loadings are shown in bold. 
Table 8. Principal component loadings of TEs in scalp hair of control $\left(\mathrm{G}_{\mathrm{c} 1}, n=33\right)^{\mathrm{a}}$, lymphocytic leukaemia (LL, $n=$ 16), and myeloid leukaemia (ML, $n=23$ ) groups

\begin{tabular}{lccccccccc}
\hline \multirow{2}{*}{ Variable } & \multicolumn{3}{c}{$\mathrm{PC1}$} & \multicolumn{3}{c}{$\mathrm{PC} 2$} & \multicolumn{3}{c}{ PC3 } \\
\cline { 2 - 10 } & $\mathrm{G}_{\mathrm{c} 1}$ & $\mathrm{LL}$ & $\mathrm{ML}$ & $\mathrm{G}_{\mathrm{c} 1}$ & $\mathrm{LL}$ & $\mathrm{ML}$ & $\mathrm{G}_{\mathrm{c} 1}$ & $\mathrm{LL}$ & $\mathrm{ML}$ \\
\hline $\mathrm{Pb}$ & $\mathbf{0 . 9 2}$ & 0.32 & 0.07 & -0.00 & $\mathbf{0 . 8 2}$ & $\mathbf{0 . 8 0}$ & 0.14 & - & - \\
$\mathrm{Zn}$ & 0.22 & $\mathbf{0 . 8 2}$ & $\mathbf{0 . 7 7}$ & $\mathbf{0 . 7 4}$ & 0.20 & 0.11 & 0.32 & - & - \\
$\mathrm{Cu}$ & -0.01 & $\mathbf{0 . 8 9}$ & $\mathbf{0 . 8 4}$ & 0.02 & 0.00 & 0.06 & $\mathbf{0 . 9 5}$ & - & - \\
$\mathrm{Ni}$ & $\mathbf{0 . 9 1}$ & -0.39 & 0.51 & 0.01 & $\mathbf{0 . 7 7}$ & -0.33 & -0.10 & - & - \\
$\mathrm{Fe}$ & 0.17 & 0.17 & -0.05 & $\mathbf{- 0 . 8 4}$ & 0.63 & $\mathbf{0 . 8 6}$ & 0.19 & - & - \\
Eigenvalues & 1.76 & 1.96 & 1.56 & 1.28 & 1.49 & 1.49 & 1.02 & - & - \\
Total variance (\%) & 35.3 & 39.1 & 31.3 & 25.9 & 29.8 & 29.8 & 20.3 & - & - \\
Cumulative variance (\%) & 35.3 & 39.1 & 31.3 & 61.2 & 68.9 & 61.1 & 81.5 & - & - \\
\hline
\end{tabular}

${ }^{\text {a }}$ Results of 33 hair samples collected from individuals aged from 23 to 63 years were participated in PCA.

Higher loadings are shown in bold.

Table 9. Principal component loadings of TEs in scalp hair of control $\left(\mathrm{G}_{\mathrm{c} 1}, n=33\right)^{\mathrm{a}}$, chronic leukaemia $(\mathrm{CL}, n=26)$, and acute leukaemia (AL, $n=13$ ) groups

\begin{tabular}{lccccccccc}
\hline \multirow{2}{*}{ Variable } & \multicolumn{3}{c}{$\mathrm{PC} 1$} & \multicolumn{3}{c}{$\mathrm{PC} 2$} & \multicolumn{3}{c}{ PC3 } \\
\cline { 2 - 9 } & $\mathrm{G}_{\mathrm{c} 1}$ & \multicolumn{1}{c}{$\mathrm{CL}$} & $\mathrm{AL}$ & \multicolumn{1}{c}{$\mathrm{G}_{\mathrm{c} 1}$} & \multicolumn{1}{c}{$\mathrm{CL}$} & \multicolumn{1}{c}{$\mathrm{AL}$} & $\mathrm{AL}$ & $\mathrm{CL}$ & $\mathrm{AL}$ \\
\hline $\mathrm{Pb}$ & 0.92 & -0.72 & 0.87 & -0.00 & 0.18 & -0.00 & 0.14 & - & - \\
$\mathrm{Zn}$ & 0.22 & 0.13 & $\mathbf{0 . 8 3}$ & $\mathbf{0 . 7 4}$ & $\mathbf{- 0 . 7 2}$ & 0.30 & 0.32 & - & - \\
$\mathrm{Cu}$ & -0.01 & 0.01 & $\mathbf{0 . 8 2}$ & 0.02 & $\mathbf{- 0 . 8 4}$ & 0.28 & $\mathbf{0 . 9 5}$ & - & - \\
$\mathrm{Ni}$ & $\mathbf{0 . 9 1}$ & 0.66 & 0.16 & 0.01 & 0.39 & $\mathbf{0 . 8 6}$ & -0.10 & - & - \\
$\mathrm{Fe}$ & 0.17 & $\mathbf{- 0 . 7 9}$ & 0.18 & $\mathbf{- 0 . 8 4}$ & 0.17 & $\mathbf{0 . 9 1}$ & 0.19 & - & - \\
Eigenvalues & 1.76 & 1.65 & 2.75 & 1.28 & 1.39 & 1.14 & 1.02 & - & - \\
Total variance (\%) & 35.3 & 33.1 & 54.9 & 25.9 & 27.9 & 22.8 & 20.3 & - & - \\
Cumulative variance (\%) & 35.3 & 33.1 & 54.9 & 61.2 & 60.9 & 77.8 & 81.5 & - & - \\
\hline
\end{tabular}

${ }^{a}$ Results of 33 hair samples collected from individuals aged from 23 to 63 years were participated in PCA.

Higher loadings are shown in bold.

loadings for $\mathrm{Pb}$ and $\mathrm{Ni}$; while, in the instance of $\mathrm{LL}$ and ML subgroups, PC1 showed higher loadings for $\mathrm{Zn}$ and $\mathrm{Cu}$. On the other hand, PC1 showed higher loadings for $(\mathrm{Pb}$ and $\mathrm{Fe})$ and $(\mathrm{Pb}, \mathrm{Zn}$ and $\mathrm{Cu})$ in the instance of CL and AL subgroups, respectively. These results indicated that for control group $\mathrm{Pb}$ and Ni contributed maximum loadings to PC1. This contribution was partially or completely changed in the instances of all leukaemia patients subgroups. However, the previously mentioned two TEs ( $\mathrm{Pb}$ and $\mathrm{Ni}$ ) were changed to $(\mathrm{Zn}$ and $\mathrm{Cu})$ in both of LL and ML subgroups. In the instances of LC and AL subgroups, Ni was changed by $(\mathrm{Fe})$ and ( $\mathrm{Zn}$ and $\mathrm{Cu}$ ), respectively; while $\mathrm{Pb}$ in last two subgroups shared again PC1 as in control group. In the control group, PC2 showed positive and negative higher loadings for $\mathrm{Zn}$ and $\mathrm{Fe}$, respectively. The maximum loadings of $(\mathrm{Pb}$ and $\mathrm{Ni}),(\mathrm{Pb}$ and $\mathrm{Fe})$, (negative $\mathrm{Zn}$ and negative $\mathrm{Cu}$ ) and ( $\mathrm{Ni}$ and $\mathrm{Fe}$ ) were shown in PC2 for LL, ML, CL and AL leukaemia subgroups, respectively. These results indicated that PC2 had different maximum loadings for the TEs in leukaemia subgroups. In addition, comparison between the results obtained for TEs in control and leukaemia subgroups demonstrated different maximum loadings in PC2. The maximum loading of $\mathrm{Cu}$ was shown in PC3 for control group, while such findings for the $\mathrm{Cu}$ or the rest TEs were absent in all leukaemia subgroups. In fact, PCA demonstrated significantly different grouping of TEs in leukaemia patients and control groups.

\section{Conclusions}

The XRF method was applied successfully for the determination of $\mathrm{Fe}, \mathrm{Ni}, \mathrm{Cu}, \mathrm{Zn}$ and $\mathrm{Pb}$ in scalp hair of leukaemia patients and control groups. The measured results of the Standard Reference Materials were in good agreement with the certified values.

Distribution of all TEs was skewed into the direction of the highest values. The wide range of the TEs concentrations in leukaemia patients was higher than that obtained for control group. On the basis of the median ranks obtained by Mann-Whitney $U$ test, there were no significant differences between the studied TEs in scalp hair of leukaemia patients and controls; whereas, an exact probability $(\alpha<$ 0.05 ) associated with the same test confirmed several significant differences between medians of the TEs in leukaemia patients and control groups.

Data on the element-to-element correlations and their ratios revealed the existence of several very strong mutual correlations in leukaemia patients and control groups, in addition to other strong and significant correlations. The correlation results indicated some common origins of the studied TEs in scalp hair of leukaemia patients. Furthermore, the correlation coefficients for the TEs in the control group were much higher than those obtained in the leukaemia patients group.

PCA showed different apportionment mechanisms of the studied TEs in scalp hair of leukaemia patients and controls. This result supported that the body metabolism in the leukaemia patients is being 
significantly affected by the examined TEs. In addition, the PCA showed that the type and the growth of the leukaemia factors affected the distribution of the TEs in scalp hair of leukaemia patients more than the age-factor.

Acknowledgments. The author thanks Prof. I. Othman, Director General of AECS, for his encouragements and keen interest in this work. Thanks are also due to the head of the Chemistry Department, Dr. T. Yaseen, for his valuable advice and discussion.

\section{References}

1. Al-Sayer, H., Mathew, T. C., Asfar, S., Khourshed, M., Al-Bader, A., Behbehani, A., \& Dashti, H. (2004). Serum changes in trace elements during thyroid cancers. Mol. Cell. Biochem., 260, 1-5.

2. Demir, C., Demir, H., Esen, R., Sehitogullari, A., Atmaca, M., \& Alay, M. (2011). Altered serum levels of elements in acute leukemia cases in Turkey. Asian Pac. J. Cancer Prev., 12, 3471-3474.

3. Fukuda, H., Ebara, M., Yamada, H., Arimoto, M., Okabe, S., Obu, M., Yoshikawa, M., Sugiura, N., \& Saisho, H. (2004). Trace elements and cancer. Japan Medical Association Journal (JMAJ), 47, 391-395.

4. Karimi, G,. Shahar, S., Homayouni, N., Rajikan, R., Abu Bakar, N. F., \& Othman, M. S. (2012). Association between trace element and heavy metal levels in hair and nail with prostate cancer. Asian Pac. J. Cancer Prev., 13, 4249-4253.

5. Kolmogorov, Y., Kovaleva, V., \& Gonchar, A. (2000). Analysis of trace elements in scalp hair of healthy people, hyperplasia and breast cancer patients with XRF method. Nucl. Instrum. Methods Phys. Res. Sect. A: Accel. Spectrom. Dect. Assoc. Equip., 448, 457-460.

6. Milde, D., Altmannova, K., Vysloužil, K., \& Stužka, V. (2005). Trace element levels in blood serum and colon tissue in colorectal cancer. Chem. Pap., 59, 157-160.

7. Tan, C., \& Chen, H. (2011). Screening cancer by analyzing trace elements in hair and chemometrics. Biol. Trace Elem. Res., 144, 97-108.

8. Abdulrahman, F. I., Akan, J. C., Chellube, Z. M., \& Waziri, M. (2012). Levels of heavy metals in human hair and nail samples from Maiduguri Metropolis, Borno State, Nigeria. World Environ., 2, 81-89.

9. Mehra, R., \& Juneja, M. (2005). Elements in scalp hair and nails indicating metal body burden in polluted environment. J. Sci. Ind. Res., 64, 119-124.

10. Hicks, J., Bartholomew, J., Ward-Smith, P., \& Hutto, C. J. (2003). Quality of life among childhood leukemia patients. J. Pediatr. Oncol. Nurs., 20, 192-200.

11. Bass, D. A., Hickok, D., Quig, D., \& Urek, K. (2001). Trace element analysis in hair: Factors determining accuracy, precision, and reliability. Altern. Med. Rev., 6, 472-481.

12. Dressler, V. L., Pozebon, D., Mesko, M. F., Matuscvh, A., Kumtabtim, U., Wu, B., \& Beckert, J. S. (2010). Biomonitoring of essential and toxic metals in single hair using on-line solution-based calibration in laser ablation inductively coupled plasma mass spectrometry. Talanta, 82, 1770-1777.

13. Gellein, K., Lierhagen, S., Brevik, P. S., Teigen, M., Kaur, P., Singh, T., Flaten, T. P., \& Syversen, T. (2008). Trace element profiles in single strands of human hair determined by HR-ICP-MS. Biol. Trace Elem. Res., 123, 250-260.

14. Khuder, A., Bakir, M. A., Karjou, J., \& Sawan, M. Kh. (2007). XRF and TXRF techniques for multi-element determination of trace elements in whole blood and human hair samples. J. Radioanal. Nucl. Chem., 273, 435-442.

15. Saiki, M., Alves, E. R., Jaluul, O., Sumita, N. M., \& Filho, W. J. (2008). Determination of trace elements in scalp hair of an elderly population by neutron activation analysis. J. Radioanal. Nucl. Chem., 276, 53-57.

16. Tadayon, F., Tehrani, M. S., \& Nia, S. R. (2012). Determination of toxic and essential elements in the scalp hair of patients with type 2 diabetes. Acad. Res. Int. . 2, 11-16.

17. IAEA. (1997). Sampling, storage and sample preparation procedures for $X$ ray fluorescence analysis of environmental materials. Vienna: International Atomic Energy Agency. (IAEA-TECDOC-950).

18. Khuder, A., Bakir, M. A., Solaiman, A., Issa, H., Habil, Kh., \& Mohammad, A. (2012). Major, minor, and trace elements in whole blood of patients with different leukemia patterns. Nukleonika, 57(3), 389-399.

19. IAEA. (2005). Quantitative X-ray analysis system. QXAS, Doc. Version 2.0. Vienna: International Atomic Energy Agency.

20. Konieczka, P., \& Namiesnik, J. (2009). Quality assurance and quality control in the analytical chemical laboratory: a practical approach. Boca Raton: CRC Press.

21. Pasha, Q., Malik, S. A., \& Shah, M. H. (2008). Statistical analysis of trace metals in the plasma of cancer patients versus controls. J. Hazard. Mater., 153, 1215-1221

22. Weiss, C. H. (2007) StatSoft, Inc., Tusla, OK.STATISTICA Version 8.0. AStA Adv. Stat. Anal., 91, 339-341.

23. Carvallo, M. L., Brito, J., \& Barreiros, M. A. (1998) Study of trace element concentrations in human tissues by EDXRF spectrometry. X-Ray Spectrom., 27, 198-204.

24. Eltayeb, M. A. H., \& Van Grieken, R. E. (1989). Preconcentration and XRF-determination of heavy metals in hair from Sudanese populations. J. Radioanal. Nucl. Chem., 131, 331-342.

25. Khudzari, J. Md., Wagiran, H., Hossain, MdI., Ibrahim, N., \& Agam, M. A. (2011). Heavy metals Mn, $\mathrm{Fe}, \mathrm{Ni}, \mathrm{Cu}$ and $\mathrm{Zn}$ in human hair samples using energy dispersive X-ray fluorescence analysis. Int. J. Phys. Sci., 6, 2090-2094.

26. Rao, K. S., Balaji, T., Rao, T. P., Babu, Y., \& Naidu, G. R. K. (2002). Determination of iron, cobalt, nickel, manganese, zinc, copper, cadmium and lead in human hair by inductively coupled plasma atomic emission spectrometry. Spectroc. Acta Pt. B-Atom. Spectr., 57, 1333-1338.

27. Sturaro, A., Parvoli, G., Doretti, L., Zanchetta, S. \& Allegri, G. (1993). Simultaneous determination of trace metals in human hair by dynamic ion-exchange chromatography. Anal. Chim. Acta, 274, 163-170.

28. Modaressi, A., Hadjibabaie, M., Shamshiri, A. R, Namdar, R., Abdollahi, M., \& Ghavamzadeh, A. (2012). Trace elements $(\mathrm{Se}, \mathrm{Zn}$, and $\mathrm{Cu}$ ) levels in patients with newly diagnosed acute leukemia. IJHOSCR, 6, 5-10.

29. Sanaat, Z., Nouri, M., Hajipour, B., Dolatkhah, R. Asvadi, I., Vaez, J., Eivazi, J., Nikanfar, A., Esfahani, A., Chavoshi, Sh., \& Biorani, H. (2011). Evaluation of copper, zinc, $\mathrm{Cu} / \mathrm{Zn}$, and VEGF in patients with $\mathrm{AML}$ in Iran. Iran. J. Cancer Prev., 4, 151-153. 